\title{
Transnational Sacralizations: When Daoist Monks meet Global Spiritual Tourists
}

\author{
David A. Palmer \\ Department of Sociology \\ The University of Hong Kong
}

PRE-PUBLICATION VERSION

Published in Ethnos: Journal of Anthropology (2012).

DOI: 10.1080/00141844.2012.714396, published online in November 2012.

\begin{abstract}
:
This article examines the production of sacrality in the context of globalization, through the case of encounters between international spiritual tourists and Chinese monks. The sacred mountain of Huashan has historically been localized in the context of Daoist cosmology, Chinese imperial civilizing, socialist nation-building and, now, global capitalism. While the monks experience Huashan as a gateway for embeddedness into Daoist lineage, ritual and cosmology, the spiritual tourists approach it as a fountain of raw, consumable energy on a path of disembedding and individuation. But encounters between the two groups lead to the mutual interference and interpenetration of both trajectories. Undermining dichotomist concepts of the sacred which define it as either essentially Other or as socially constructed and contested, the sacrality of Huashan serves as both an anchor for multiple centralizing projects and forces, and as a catalyst and node for the formation of interconnecting and expanding horizontal networks.
\end{abstract}

When the Daoist monks at the Jade Spring Monastery 玉泉院 on the foot of Huashan 華山 conduct the ritual to the Dipper on the day of Gengshen 庚申, the temple, closed to tourists for the evening, is deserted save for the monks gathered for the recitations in the main shrine devoted to the immortal Chen Tuan 陳摶, patron of Inner Alchemy. But, on 30 May 2006, a different scene presented itself. On either side of Chen Tuan, eight Daoist monks in their blue robes and black caps solemnly chanted the Scripture to the Northern Dipper 北斗經, following the dreamy cadence of knocks on the hollow wooden fish, holding tablets, bowing, kneeling and standing, their backs to the temple's central court. Darkness had fallen and the 
light in the shrine only faintly illuminated parts of the court, into which meandered wafts of incense smoke, hesitating between motion and stillness. Around the heavy stone and iron incense burner in the middle of the courtyard, scarcely visible bodies turned in the shadows, some in unison, stretching and contracting, others in spontaneous motion, while others sat in quiet meditation on steps and ledges, a few in the lotus position, some with their knees to their chests, dispersed at various spots of the small temple enclosure, while a young couple held each other in embrace, their minds mingling as clouds of vapour in the obscure stillness punctuated by the monks' grave chanting and hollow knocking.

They came from all over, thirty of them, doing qigong, Taijiquan, inner alchemical meditation, yoga, or just sitting there. There was a martial arts teacher from Mexico, a Sufi seeker from Seattle, a fengshui consultant, a Colorado Shaman, a few earnest youth, others rather jaded, a Japanese secretary and a Turkish psychotherapist, a banker, a neuroscientist, several retirees, and a French vineyard owner.

In the inner altar, the Quanzhen Daoists chanted, stood in a single line and bowed, facing South; in the outer yard, the foreigners did qigong exercises in all directions, many of them facing North: two groups, Chinese and international, their backs to each other, in their own worlds, doing their own rituals. But both groups felt each others' presence and a shared peaceful atmosphere. After the ritual ended, the monks distributed the fruit offerings watermelon and bananas - to the foreign group members.

Few words were exchanged that night. Over the next few days, the foreigners continued their hiking around the Five Peaks of Huashan, and the most adventurous marched down and up the adjacent mountain to a remote - and off-limits to tourists - cliff ledge and meadow, where they were met with open arms by the resident hermit, Master Hao. They stayed there for several days of meditation in caves, "connecting with the powerful energies of the mountain".

This ethnographic vignette describes the encounter of two groups of Daoist practitioners, coming from vastly different cultural and religious backgrounds, at a common sacred site. For the Chinese monks of the Quanzhen monastic Order, Huashan is steeped in sacred history: one of the Five Imperial Marchmounts (wuyue 五岳) of China, a major Daoist Grotto Heaven (dongtian 洞天), an important site in the historical genealogy of the Daoist spiritual practice of inner alchemy, and a way-station in the past and present practice of 
“cloud wanderings" (yunyou 雲遊) of Daoist monks in their travels from one monastery to another throughout China. For the international spiritual tourists, Huashan is a stop on the itinerary of "Dream Trips," group tours organized by a leading American commercial provider of training programmes in the Daoist traditions of gentle breath, body and mind exercises commonly known as qigong 氣功 ${ }^{1}$ - an itinerary that combines sight-seeing, shopping, and qigong practice and meditation at major Daoist temples and mountains. The international participants, for the most part, have little knowledge of or interest in the geographic, historical, and religious significance of these sites: for them, the mountains are spaces for generating embodied experiences through qigong practice, and for connecting with the powerful energetic imprint left by past generations of anonymous Daoist hermits and cultivators. Such visits began in the early 2000s and are increasing in frequency, and are now offered by most American Daoist organizations (Siegler 2006, 2010, 2011). These encounters between Chinese Quanzhen monks and primarily Western spiritual tourists are moments in the "return globalization" (Frøystad 2009) of Daoism, when practitioners of an Americanized Daoist practice meet with indigenous exponents of the tradition. Both groups share the experience of the "portable practices" (Csordas 2009: 4-5) of Daoist body cultivation and meditation, but live worlds apart in terms of the social trajectories and environmental contexts of their "Daoist" experience. Both groups cross paths on Huashan, physically and figuratively, in monasteries and mountain trails, at different points of their trajectories in life and in their paths of Daoist cultivation. How are these encounters inflected by the sacrality of the place, and how do they impact on it in return?

In this article, I consider the interplay between environment, experience and memory in the production of sacrality and locality at Huashan, during the specific moments of "grip" and "friction" which constitute the "concrete encounters" which, connected to each other, are the instantiations of a globalization often conceptualized in terms of abstract "flows" (Tsing 2005). Research was conducted through participant observation in 2004 and 2006, and interviews held with Daoist monks at Huashan - notably my main informants, "Master

\footnotetext{
${ }^{1}$ Qigong is a neologism which gained currency after the medical authorities of the Peoples' Republic of China attempted to secularize and modernize the practices in the 1950s. See Palmer 2007 for a socio-political history of qigong in modern China. For ethnographic studies of qigong in post-Mao China, see Hsu 1999, Chen 2003 and Palmer 2008. For a historical overview and technical description of many of these practices in pre-modern times, see Kohn 2008.
} 
Wen," "Master Hu" and "Master Hao"' during further visits in the summers of 2007, 2008, 2010, and $2011 .^{3} \mathrm{I}$ begin by considering how locality and sacrality at Huashan have historically been constructed and contested in the context of supra-local projects and forces including Daoist cosmology, Chinese imperial civilizing, and socialist nation-building. Global capitalism creates a new context for Huashan, localizing the mountain as a stop in the transnational itineraries of spiritual tourists. But such a top-down view of the construction of Huashan may blind us from the agency and experience of place of the Daoist practitioners who circulate and meet on the mountain. Beginning in the second part of the article, I offer a micro-ethnographic study of how Daoist techniques of spiritual cultivation are embodied by both Quanzhen monks and Dream Trippers to position themselves in relation to sacred space. I question the dichotomies between body, space and culture which pervade much theorizing on the concept of the sacred. Drawing on the work of Tim Ingold (2000) on body and environment, I propose a dynamic model of sacralization as a process through which conscious bodies are physically drawn into the presence and memory of significant features of a place, thereby differentiating a landscape, generating experience, and enriching the memory which points the way for future practitioners to walk the same path. Undermining dichotomist concepts of the sacred which emphasize it as either essentially Other or as socially constructed and contested, what appears from the study is a sacrality of "dwelling" (Ingold 2000: 173) in which practitioners perceive (in the form of embodied experience) and augment (in the form of generated and transmitted memory) the sacrality of a mountain understood not so much as a fixed location in space but as a history of movements through that location. Sacred places, as loci for intense interactions and mutual embedding between human society, the non-human ecology and cultural memory, become anchors and nodes in the socio-ecological "regions" constituted by movements between places. However, different human groups are characterized by different patterns of movement and memory, inscribing the sacred place into different cycles, trajectories, mappings and projects. The third and fourth sections use this perspective to compare how the international spiritual

\footnotetext{
2 Pseudonyms

${ }^{3}$ This project was conducted in collaboration with Elijah Siegler of The College of Charleston, as part of a study on transnational encounters between international (primarily American) "Daoist" practitioners and Chinese Quanzhen monks. For other publications emanating from this study, see Siegler 2010, 2011, Palmer forthcoming, and Siegler and Palmer forthcoming. My field research for this project was made possible thanks to grants from the Sociology Department of the London School of Economics and the French Centre for Research on Contemporary China.
} 
tourists and the Chinese monks "dwell in" and "map" Huashan in their respective paths of spiritual cultivation. For the spiritual tourists, Huashan is a fountain of raw, consumable energy on a path of individuation and self-discovery; for the monks, Huashan is a gateway into Daoist lineage, ritual and cosmology.

The Huashan which is experienced and produced as a sacred site embodies not only the physical mountain and its energies, but the narratives, memories and cosmologies within which it is mapped. To the extent that the latter differ, the two groups which cross paths at Huashan dwell in different but overlapping sacred places. At the same time, however, the encounters disrupt and modify the trajectories of some of the participants, who are drawn further into the other group's circuits, without necessarily cutting themselves from their previous histories and networks. The result, in this micro-study of a particular "ethnoscape" (Appadurai 1996) in the globalization of Daoism, is neither "homogenization," nor a "clash of cultures," nor even "hybridity" (Nederveen Pieterse 2009), but a process of "interpenetration" of ever-evolving and expanding networks. And thus, while a sacred place serves as an attractor and anchor for vertical, supra-local projects and hegemonic forces, it also acts as a catalyst for the formation of horizontal rhizomatic networks (Deleuze and Guattari 1980). The sacred locality of Huashan acts as both a differentiating and connecting node in the intermingling of human paths of life.

\section{Producing Locality}

An important theme in the theory of globalization has been how globalizing processes, rather than simply producing universal uniformity, are also constitutive of the local - which "is in large degree constructed on a trans- or super-local basis... Much of what is often declared to be local is in fact the local expressed in terms of generalized recipes of locality" (Robertson 1995: 26). Globalization produces a dialectic in which different localities are placed in relation with each other, highlighting their difference and their uniqueness but, typically, following a standard pattern within a single, supra-local framework.

The history of Huashan shows, however, that the production of locality within translocal or supra-local contexts does not begin with globalization. In local lore, the mountain's powers, considered the lair of sprites, demons, and ogres, are said to have been domesticated by the sages and immortals of Daoism as a supra-local religious institution 
(von Glahn 2004, Schipper 2008). Near the Western Peak of the mountain lies a temple, the Palace for Pacifying the Summit (Zhenyuegong 鎮岳宮), whose name implies the act of possessing and subjugating the mountain, and which enshrines the mountain's tutelary god. As Appadurai has noted, much of the ethnographic archive of anthropology describes "ways to embody locality as well as to locate bodies in socially and spacially defined communities" (Appadurai 1996: 179). These communities have tended to constitute themselves in opposition to nonhuman, barbaric or demonic forces, and the production of locality involves the subjugation, domestication or colonization of these forces, requiring "deliberate, risky, even violent action in respect to to soil, forests, animals, and other human beings. A good deal of the violence associated with foundational ritual is a recognition of the force that is required to wrest a locality from previously uncontrolled peoples and places... The production of a neighborhood is inherently colonizing, in the sense that it involves the assertion of socially (often ritually) organized power over places and settings that are viewed as potentially chaotic or rebellious" (183-184). And in complex societies, this colonization is often effected through the codified, supra-local knowledge and rituals of priestly classes.

The Daoist domestication of the god involved sages and immortals taming its energies, and giving him a rank and title in the Daoist pantheon -- as the Great Lord of the Western Marchmount, Xiyue dadi 西岳大帝 -- honouring his powers, but subordinating him to even higher Daoist divinities. And he was also integrated into the imperial civilizing cosmology, as one of the Lords of the Five Marchmounts, the sacred mountains marking China's five cardinal points, forming the imperial realm into a single mandala and guarding the frontiers on all sides against barbarian and demonic invasion (see Dott 2005, Robson 2009). The Emperor, in his tours of the realm, conducted rites to honour the Xiyue dadi at the sprawling Temple of the Western Marchmount (Xiyuemiao 西岳廟) built in the plain near the mountain's foot, with a layout similar to that of the Forbidden City in Beijing. Daoism, as an important source of imperial legitimacy (Lagerwey 2010), was an instrument for the Chinese state's cosmological and religious colonization of Huashan. The Daoist memory of Huashan, then, is one of the conquest, domestication, and integration of the mountain's powers into the sacred structure of the imperial Chinese state and into the universal cosmology of the Daoist religion. The locality and sacrality of Huashan is thus 
constituted in this supra-local framework, which no longer exists politically, but lives on as a powerful presence in historical memory.

In the contemporary "global production of locality," Appadurai notes, a tension often arises when the nation-state becomes the overwhelming context for the production of locality, restricting the capacity of neighbourhoods to produce locality by generating their own contexts. "The nation-state relies for its legitimacy on the intensity of its meaningful presence in a continuous body of bounded territory. It works by policing its borders, producing its people, constructing its citizens, defining its capitals, monuments, cities, waters and soils, and by constructing its locales of memory and commemoration, such as graveyards and cenotaphs, mausoleums and museums" (Appadurai 1996: 189). Huashan has been colonized again, this time by the socialist nation-state. But where the imperial colonization of the mountain involved integrating its powers into the sacred cosmology of the state and the pantheon of the Daoist religion, the socialist subjugation has sought to exclude and marginalize the mountain's sacred powers and history. Celebrated in the 1950 s by a revolutionary film on the “Conquest of Huashan” 智取華山 by Red Army soldiers, the political occupation shifted its focus in the 1980s to commercial tourist development, focusing exclusively on scenic beauty and almost completely sidelining its history and religious sacrality (Andersen 1990) - unlike many other tourist sites in China, where state actors have attempted to promote and market the "cultural resources" of religion to stimulate the tourist economy (Oakes and Sutton 2010). The Palace for Pacifying the Summit, mentioned above, is now partially occupied by a commercial guesthouse which, during my first visit, filled the temple's surroundings with blaring hip-hop. Huashan monks speak passionately about how the mountain belongs to Daoism, and has been unjustly taken over by the provincial government's tourism corporation, which placed toilets in one shrine and a karaoke bar in another. Huashan monks were notorious for triggering violent incidents in the late 1990s, in which fights and brawls frequently occurred with corporation staff and even senior government leaders. The locality of Huashan is now one of uneasy juxtapositions and "micro-struggles over space" (Yang 2004).

International Dream Trippers and other groups of spiritual tourists create another global context for the production of locality at Huashan. Though it is too early to draw firm conclusions about the impact of globalization on Huashan as a sacred site, we may detect an incipient "glocalization" of the mountain (Robertson 1992). Huashan is added to spiritual 
tours because it meets a certain number of standard criteria for "energy power spots," which would include places sufficiently off the beaten track but within convenient access to confortable accommodation and transportation, places and activities producing distinct energy experiences, extraordinary scenery, and a special atmosphere of religious authenticity - the presence of "real" monks, for instance, who are genuine Daoist cultivators and able to impart teachings to group members. For each of these criteria, the uniqueness of the locality is highlighted, but within a standardized, a-historical framework of expectations which allows Huashan to be placed in a sequence of other sacred energy sites in the itineraries of global spiritual tourists. Group members are consumers, whose relationships may not last beyond the three-week trips to China. The Western Daoist organizations and networks within which many of them circulate in America and other countries are mostly commercial operations selling retreats, courses, books and, increasingly, tours to China. International spiritual tourism would then represent another colonization of the mountain, this time by the commodifying flows of global capitalism.

\section{Sacrality as experience or social construction}

In such an analysis, however, the mountain tends to appear as an undifferentiated surface onto which competing projects inscribe themselves and confront each other. How do the individual practitioners on the mountain experience and engage with the place? How do they embody these projects and circulate between them? How do they transform the place, and how does the place transform them? As a sacred site, Huashan is not an ordinary locality; it is associated with dense strands of history, memory and experiences of power; it is this sacred dimension which attracts monks and spiritual tourists today, which the Maoist state tried to obliterate a few decades ago, and which the imperial state tried to harness centuries earlier. How can we understand the feedback loops between the physical environment, individual practice and experience, and these collective memories and powers? When Daoists meditate at Huashan, are their narratives merely instantiations of broader cultural and political projects, so that, while they think they are experiencing the powers of the mountain, they are actually merely experiencing its cultural representation? These

questions force us to revisit the concept of the sacred, and to shift our perspective to a 
micro-ethnographic study of the practices and experiences of those who engage with a sacred place.

Most theories of the sacred posit a dichotomy between subjects and objects of sacrality - the "sacred" is either something pre-existing and distinct from the subject, which erupts into his experience, or is an artifact purely dependent on social constructions. The first type of dichotomist view, exemplified by Mircea Eliade, sees the sacred as essentially Other: "In actual fact, the place is never 'chosen' by man. It is merely discovered by him; in other words, the sacred place in some way or another reveals itself to him" (Eliade 1958a: 369). Elsewhere, he states, this "is not a matter of theoretical speculation, but of a primary religious experience that precedes reflection on the world" (Eliade 1958b: 20-21). Sacred places thus share a mystical unity with the ultimate being or reality; the best approach to them is thus to let them be, and approach them with awe and reverence. Therefore, pilgrimage should be an unmediated experience of the sacred reality, leaving it untouched and pristine. Or, in the words of Belden C. Lane: "Sacred place, we have said, seems to have an unaccountable identity distinct and separate from those who move in and through it" (Lane 2002: 24).

In radical contrast to this essentialist view of the sacred, a Durkheimian perspective would claim that the sacred is first and foremost the product of social and cultural forces. In his definition of religion, Emile Durkheim argues that all cultures classify things and ideas into the two categories of sacred and profane, conceived of as "separate genera, two worlds which have nothing in common." (Durkheim 1994[1913]:115) The boundaries between the two worlds are marked in any culture; approaching the sacred always requires special rules and procedures; and entering the sacred world involves a process of metamorphosis or transformation (116). However, the idea of the sacred does not emerge from the sacred objects themselves; rather, it comes from the experience of the moral force of society which is impressed on individuals through the imposition of norms of conduct and through the "collective effervescence" of periodic rituals. The sacred object is a mental representation of this moral force, which is transferred onto the object; the sacred object is thus perceived as imbued with a divine power which is none other than the power of society (124-133). In the Durkheimian analysis, then, the sacred experience is entirely of a social nature, and the choice of sacred things is purely arbitrary - the sacred is the result of social agency. Ritual acts at sacred places are not so much designed to establish and manage contact between 
humans and an essentially other reality, but to construct or reproduce a certain place or thing as a representation of the social power. And such a construction is thus always an act of a group's appropriation of the place (Pahl 2003: 42). In the words of Chidester and Linenthal, "sacred space is inevitably contested space, a site of negotiated contests over legitimated ownership of sacred symbols... Power is asserted and resisted in any production of space, and especially in the production of sacred space. Since no sacred space is merely "given" in the world, its ownership will always be at stake. In this respect, a sacred space is not merely discovered, or founded, or constructed; it is claimed, owned, and operated by people advancing specific interests" (Chidester \& Linenthal 1995: 15).

Our study at Huashan shows the possibilities and limitations of both perspectives. On the one hand, the place imposes itself even to the untrained observer; the experience of awe, power and beauty which it impresses on the visitor or pilgrim is hardly arbitrary. On the other hand, the site is heavily overlaid with cultural and historical connotations, and inscribed within several cosmological and political schemas symbolically linking the mountain to the essence of the Chinese nation and its collective power. The Daoist sites and practices on the mountain use a culturally-determined framework of techniques, narrative and lineage to induce practitioners into a heightened sensitivity to the sacred powers of the mountain. The international groups of practitioners on the mountain come with their own memories and sets of meanings and are engaged in a process of appropriation, often in tension with the multiple layers of meaning and sacrality attached to the mountain by other religious groups, institutions, and political regimes (Palmer forthcoming; Siegler and Palmer forthcoming). Indeed, there is a dialectic between the place as a source of raw, unmediated, powerful experience, and the socio-cultural constructions which induce, reproduce, record, interpret, and structure those experiences.

Both the essentialist and social perspectives thus produce a dichotomy between the perceived environment and human agency. In the former, the sacrality of a place is possible only insofar as it is completely external to and untouched by human agency; in the latter, insofar as the significance given the environment is the product of human agency, the external environment in and of itself is of no significance, it is only the cultural representations and social appropriations of the environment that matter.

Both perspectives reproduce a binary ontology which is critiqued by Ingold in The Perception of the Environment (2000). Rather than seeing organisms, objects and the 
environment as discrete entities acting on each other, Ingold argues that the human being should be seen as "a singular locus of creative growth within a continually unfolding field of relationships", whose characteristics arise "as emergent properties of the fields of relationship set up through their presence and activity within a particular environment." (p. 4-5) From such a perspective, the question becomes how, by walking, climbing, breathing, stretching, meditating, and engaging in other sequences of embodied activities at different locations on the mountain, a field of relationships comes into being within which a person's growth unfolds. This field puts in relation with each other the biological and mental processes of the practitioner, the range of perceptions arising from the plants, trees, stones, temples, statues, cliffs, clouds and other beings enveloping the practitioner, the other individuals present, their words and actions, and, I will argue below, the remembered knowledge, symbols and narratives evoked by the setting.

At the same time, for Ingold, a place is also an organic process, a locus of relationships and transformations between beings, both animate and inanimate. A mountain such as Huashan, for example, is not merely a mound of static, empty, undifferentiated matter onto which humans affix external cultural concepts and meanings: it is the instantiation of the interplay of countless cycles and rhythms, ranging from geological movements and chemical transformations spanning hundreds of millions of years, giving the mountain its powerful upward thrust and its clashing sharp ridges and colossal molten curves, to the life-cycles of the soils, trees, plants, animals and insects inhabiting, layering, burrowing and criss-crossing its surfaces and crevices, to the centuries of human paths being worn down, caves being dug, temples being erected, and of the rhythmic flows of monks, pilgrims and tourists ascending and descending, entering and transforming, meditating, praying and photographing, over the cycles of day and night, and of summer and winter seasons.

To walk on Huashan, then, is to bring the field of relationships of one's own organism into the field of relationships of the mountain, each inflecting the other. But not all visitors will engage with the mountain with the same depth and intensity. For many, a visit to Huashan is little more than passing by, both literally and figuratively touching only the surface of the mountain. Others, however - including our monks and spiritual tourists engage more fully with the place, seeking and finding deep significance in spots, experiences and encounters along the way, and, literally, penetrating the depths of the mountain by 
sojourning in its caves. The sacrality of a place, then, emerges from the intense interpenetration of the fields of relationships of human organisms, collective memories, and of the place itself. The sacred place becomes a node at which these fields continue to interact in time and history, leaving an imprint on the place itself, the collective memory, and the lives of those individuals who orient themselves in relation to the place.

To be attentive to the landscape in such a way, and to enhance one's capacity to enter into relation with the place, one generally needs to undergo a process of education in practice and perception (Ingold 2000: 5-6). It is through such a process that the Chinese Daoist monks and international Dream Trippers move into the environment of Huashan, and perceive and engage with the mountain in a manner different from most tourists, relating with what they perceive to be the spiritual powers of the mountain. Part of the process involves training in the Daoist disciplines of body, breath and mind, which sharpen the organism's dispositions and perception of environmental forces and settings. The organism's sensitivity is thus enhanced, and a landscape which, for the untrained observer, is primarily visually perceived and thus differentiated only in terms of colour, texture and perspective, as if it were seen on a flat screen, becomes, for the skilled practitioner, a world of moving forces, energies and even intentions. These are perceived and experienced by the whole organism, itself a field of circulating energies and interactions, which intentionally interacts with and may even attempt to transform the environmental field of forces. The "sacred" place, then, is one which is differentiated from other places by the high intensity of such perceptions, forces, and interactions. The dichotomy between the essentialist and constructivist views of the sacred is here overcome by the fact that practitioners do experience something powerful beyond themselves and which is associated with a particular spot, but it is through a cultural process that the organism gains the dispositions which enhance its sense of "dwelling" in a spot and its holistic sensitivity to, and engagement with, the field of forces brought into consciousness by their moving into that spot.

This process, however, is not limited to the mastery of a regimen of embodied disciplines. The environment in which the organism moves is not only physical, but symbolic as well; significant places at Huashan are marked by temples, poems carved in stone, shrines, deity statues and other features which trigger responses and associations in the practitioner's memory of previous experiences and knowledge of the symbol systems from which they are drawn. Sacralization is also a process of growing into, dwelling in, experiencing, and adding 
to a collective memory, itself generated through the experience of the place. A sacred place is characterised by a high density of collective memory; to approach and enter it is to viscerally experience and interact with these memories, and to recall, enrich, and reinforce them in one's mind. The field of relations brought into play by pilgrimage and the encounter with a sacred place thus connects the pilgrim, the place, and the symbols and memories associated with the place and with past pilgrims.

The "dwelling perspective" proposed by Ingold contains useful insights to understand this process. Ingold argues that "while dwelling in the world entails movement, this movement is not between locations in space but between places in a network of coming and going [...] To know one's whereabouts is thus to be able to connect one's latest movements to narratives of journeys previously made, by oneself and others. [...] I develop a notion of mapping as the narrative re-enactment of journeys made, and of maps as the inscriptions to which such re-enactments may possibly give rise." (155) The "ensemble of place-to-place movements" constitutes what Ingold terms a "region" (229).

The Chinese and international practitioners are linked to different networks of coming and going; they connect to and re-enact different narratives of journeys previously made to Huashan. Since both groups constitute different networks of movements, they form different "regions", and their "mappings" of the mountain are different. What are the "regions" of the monks and spiritual tourists? And what is the position and role of Huashan as a sacred place within both "regions"? In order to answer this question, we need to consider where the actors are coming from and where they are going (both in a material and symbolic sense), how they pass through the mountain, how they engage with it and experience it, and how they situate Huashan in broader narratives, memories and cosmologies. We find that the movement of the spiritual tourists is one of cultural, historical and social disembedding: the journey is one of individuation, of discovering and expanding the self, and the encounter with Huashan seeks to directly experience and activate the mountain's powers, disembedding them from Daoist history and lineage. Huashan becomes a power source in a global circuit of consumable spiritual energy. The Quanzhen monks, on the other hand, emphasize the deep memory of place, history, and practice, and experience and produce Huashan as a gateway into the world of Daoist cosmology and lineage. Their movement involves activating memories of former monks and immortals who walked in, 
lived in, and even crafted the mountain in bygone times; the path of Daoist cultivation, for them, involves embedding oneself into lineage, ritual, norms of virtue, and cosmology.

\section{The Dream Trippers: Engaging with Energies}

The Dream Trip “mission”, as presented on the Healing Tao USA website, describes the trips as a spiritual journey, a connection with powerful Daoists and Qi currents, and a gastronomical delight:

To experience the spiritual essence of China. To meet \& study with spiritually powerful Daoists. To do qigong in its most sacred and beautiful landscapes and connect to its ancestral chi. To deeply taste China's ancient culture and peoples, and feast on its local cuisines at sumptuous banquets. To share the very best secrets I discovered on previous trips to China - before it disappears in China's madly modern rush to forget its rich history. In short, The Dream China Trip I would give to myself, if I could only visit China once. [...] The trips are designed to keep the door open between Western and Asian Daoist adepts, and to deepen the ground of our personal practice. Our qigong practice will connect us to the uniquely powerful Qi currents flowing in China's sacred mountains. If your heart feels drawn to China's mystery, I advise you to trust your soul's guidance, and trust the Tao will supply the time and resources to GO." (http://www.healingdao.com/chinatrip2010.html, accessed 9 Nov. 2010)

Tour itineraries also include plenty of time for shopping and sight-seeing at destinations such as the Great Wall, the Terracotta warriors in Xi'an, and the Potala Palace in Lhasa - a "Dream Trip" in which the conventional tourist itinerary is maintained and executed, but onto which is added a deeper, more powerful and spiritual connection to the land being visited. The highlights of these groups' itineraries are visits to Daoist sacred mountains and interactions with Quanzhen masters who impart teachings to them -- a form of pilgrimage, then, in which the travelers connect themselves with the places of origin and the living embodiments of the Daoist tradition (Naquin \& Yu 1992; Verellen 1998). "Why are China Dream Trips so special, and very different from typical tourist trips? We attract a fabulous group of Tao-minded spiritual adventurers. Not mere curiosity seekers or jaded tourists, but fascinating folks who are excited about literally following in the footsteps of Lao tzu and doing powerful qigong ceremonies in China's highest spiritual energy spots." (http://www.healingdao.com/chinatrip2010.html, accessed 9 Nov. 2010) 
Besides "following in the footsteps" of Laozi, they also connect themselves to the narratives of other past travelers to Huashan. They talk of connecting to the energies of past cultivators in the sacred mountain, but, other than Laozi himself, these remain unnamed: it is only their energies which are felt. Michael Winn, organizer of the tours, himself described powerful experiences in one of the Huashan caves:

After I finished saying all my thanks, an extraordinary thing occurred. My mouth was suddenly filled with a ball of pulsating energy, which slowly moved down my throat and esophagus into my stomach. Remarkably, this chi ball stayed in my gut during my time in the cave, and I am certain accounted for the fact that I never once felt even slightly hungry for the entire five day cave fast! Since this occurred immediately after my meditation thanking the cave, it felt like a clear communication from the mountain. [...]Some invisible presence within Huashan mountain seemed to be actively pushing me deeper into Daoist practice at every moment (Winn n.d.).

Such descriptions, and the testimony of tour participants, are highlighted in tour promotional materials, attracting other practitioners to experience the mountain's powers as well:

The Qi (chi) I experienced in China was simply mind blowing. I got a transmission from being in those mountains that has totally opened up new levels of my inner vision.

But then some crazy stirrings happened in the lower tan tian ${ }^{4}$. Rumbling, earthquake... explosion in my head. Feeling pressure.. mouth open wide, eyes shut tight, indescribable feelings in whole body... then boom!! It expressed through me as great laughter, I laughed like never before, my whole body was shaking in laughter, my lungs gasping for breath, my eyes tearing like crazy from laughter... Then crying...like never before crying and crying.. Then dancing and spinning like never before. (Testimonly from two participants in the Healing Tao website, ibid.)

These testimonies of powerful experiences, published on the Healing Tao website, provided narratives to which future participants could aspire to connect to. And Dream Trippers whom we interviewed on Huashan had similar experiences to tell:

This trip again gave me the incredible opportunity to connect with the land and people in places of the world where there has been an ancient and continuous presence of powerful meditation practitioners. The result of this has been that I have developed a deeper

${ }^{4}$ A point in the lower abdominal region, which is an important energy centre in Daoist inner alchemy. 
connection with my inner self through the inner self of many other people (as well as the earth self) as a collective experience.

I can't really tell anyone what went on in there....too much...

A very soft energy, welcoming, spiraling, as if someone was sending me energy.

The "mapping" of Huashan by the Dream Trippers clearly involved describing and experiencing the mountain as a site laden with powerful energies. But the trips also aimed to re-activate and domesticate those energies, both within the mountain and among the Chinese people. Tour participants were given the role of "Ambassadors of the Tao" by Winn, had little interest in the religious expression of Daoism as it exists in Quanzhen monasticism, and saw themselves as practitioners of a "true" way they consider was lost in Communist China - a form of silent missionizing, then, in which the travelers, through their $q i$, reinject a lost authenticity into the sites they pass through and, through their public practice of qigong, deliberately aim to shock Chinese observers into reconsidering their own spiritual tradition: "when forty foreigners come to cultivate at Qingkeping, says Winn, more than doubling the population of Huashan valley, it shakes [the Chinese Daoists] and awakens them to the value of what they are doing." "The Chinese are more lost than Americans", said one group member, while another considered that "The Daoists [in China] for the most part, except at Huashan, are far far behind us pracitioners in the west and they don't seem to care ... the Chinese people do not have any reverence for the sacred sites we visited. We went there and showed them what they could be again....." Or, in the words of another, "It's us the Americans that are going to preserve it... We seem to be the historians... Maybe we will ignite something."

The posture of the Dream Trippers, then, is not one of mere sightseeing, nor of coming from afar to seek wisdom from true masters. The tours are not so much about China or about Chinese Daoism, but about connecting with an energy which is ignored by the Chinese and even most Daoists: "That's the whole point," Winn told me. "The Tao is universal. The Chinese people walking on these mountains may or may not be connected to it, but that's not my concern". The living Daoists of today are only secondary to what the groups are seeking, which is the energies opened up by the cultivators of past eras: "That's why we come to China," he continued. "The Daoists have been in communication with these non-human energies for thousands of years. The channel of communication has been opened by them. These energies exist elsewhere too, but in those places they have not been communicated with. Here, the energies are used to being communicated with over such a 
long time. We tread along a path that has already been treaded". Who those past Daoist cultivators were, however -- their names, their lives, their lineages -- is of little interest. What matters is that they have opened energy channels which can now be directly accessed - but only after the Dream Trippers "re-open" the channel, which had closed up through long years of neglect, by "taming" the energies: "at first," said Winn, "a few years ago, the energies were no longer used to being communicated with [owing to so few Chinese cultivators in recent times and to the unprecedented arrival of foreigners], so the experiences were hard to deal with. Now, they are more used to it; there have been more foreign meditators here; the powers have become more manageable."

\section{The Chinese Monks: Embedding Techniques}

When the Dream Trippers practiced Winn's qigong method, they were engaged in a process which trained them to increase their perception of "energies" in the mountain, itself part of a longer, conscious process of overcoming Western mind-body dualism and becoming more connected and attuned to their own bodies. Mapping such powerful embodied experiences was thus an important dimension of the Dream Trips, and qigong techniques practiced before, during and after the trips are essential for preparing, enhancing, and reviving those experiences. At the same time, the modern project of qigong is to detraditionalize Chinese body cultivation, to isolate it from a historical matrix of social relationships, making them accessible to secularized modern individuals of any background, even those with no knowledge of their Chinese origin, and made available in instructional books and DVDs, so that it is possible to learn the techniques without the guidance of an instructor (Palmer 2007).

Turning qigong into a detraditionalized technology, however, goes against the grain of traditional learning as defined by Ingold, in which "technical skills are themselves constituted within the matrix of social relations" while the "externalization" of mechanical technologies in the industrial era "replace[s] subject-centred skills with objective principles of mechanical functioning"... "a process of disembedding of the technical from the social, ultimately giving rise to the modern, institutionalized separation of technology and society" (Ingold 2000: 289-290). While Western qigong practitioners typically aspire to a more holistic, less 
"mechanical" orientation toward life, the disembedding of qigong into sets of technical procedures remains aligned with the overall process of externalization. And it was on this point that a great distance separated the discourse of the Chinese Quanzhen monks from that of the Dream Trippers. The Quanzhen monks insisted on re-embedding body cultivation techniques and sacred places into a broader process of dwelling within a matrix of social relations, historical genealogies and narratives, moral orientations and ritual practices.

Experiencing the powers of the mountain and enhancing the experience through the use of meditation and body techniques, are only a part the Quanzhen monks' narrative their "mapping" - of Huashan. When Master Wen spoke of the mountain, he listed the geneaology of great Daoist figures such as the Yellow Emperor 黃帝, Laozi 老子, Lü Dongbin 呂洞賓, Hao Datong 郝大通, Chen Tuan 陳摶, Qiu Chuji 丘處機 and Wang Changyue 王常月, among others, who are said to have cultivated on its peaks and in its caves. These figures stand on their own in Daoist history, however, and are not associated exclusively with Huashan or any other Daoist sacred site. Huashan itself is only one of a network of dozens of Daoist “Grotto Heavens and Blissful Realms" (dongtian fudi 洞天福地), mystic mountains and caves found throughout China, and believed to be interconnected through mysterious, invisible passages. In the monastic practice of "cloud wandering", in which monks travel from one monastery to another across the realm, staying a few months or years in one place before moving onwards, they travel through, in their embodied experience, the cosmic geography of the Daoist tradition, connecting their own trajectories with those of past generations of "wanderers" (Herrou 2011). It is in this body of memory, recorded in texts and in the narratives of great Daoists in history, that the Quanzhen monks dwell. When they move into Huashan, the place they connect with is much more than the physical mountain and its field of forces; it is also a mountain of memories and of associations, a location in the Daoist cosmos. The experiences of the body and of sacred places are significant only insofar as they can help to draw the practitioner into that cosmos, and within that cosmos, to further progress toward the ultimate generative Origin. For the monks of the Quanzhen Order, which sees itself as the most refined and complete expression of the Daoist tradition, and has for several centuries been the most highly institutionalized and elitist form of Daoism in China, the experiences generated by the practice of body techniques, and/or one's presence in a powerful sacred site, can only been 
seen as part of the process of cultivation, and even then, of no use if not integrated into a far vaster cosmology.

In a subtle fashion in their talks to the Dream Trippers, and more explicitly in private discussions with me, the Quanzhen monks emphasized that Daoist cultivation cannot be reduced to the practice of the inner-alchemical and qi-circulation techniques which the Westerners were drawn to. In various contexts and conversations, they repeatedly mentioned that "all these techniques are useless" in the absence of Daoist faith, virtue and morality, lineage and master, and the practice of religious rituals. Through this discourse on cultivation, the Quanzhen Daoists defined themselves in opposition to lay masters and practitioners, be they Chinese or foreign, of Daoist techniques such as qigong, inner alchemy, martial arts, Chinese medicine or even sexual cultivation. While the Quanzhen monks don't object to these techniques per se, what they object to is the instrumental use of the techniques, in which they are practiced to achieve a specific goal. The very characteristics that enable these techniques to easily lend themselves to modern, even scientific, instrumental rationality, and have thus become so popular in modern culture -- both in China and the West -- is what the Quanzhen Daoists refuse: true cultivation, for them, springs from inner motivation or spiritual nature; but it can be expressed, trained, and refined through a variety of practices and techniques. “The main issue in Daoist cultivation is xinxing 心性 (heart-nature), dao 道 and de 德 (virtue). This is the difference with qigong," said Master Wen. No technique can intrinsically lead to or enhance cultivation, and practicing techniques for instrumental goals does not automatically lead to progress in cultivation. From this perspective, body and meditation practices are but partial elements of a much broader and deeper process of Daoist cultivation. "Some people will take little parts or techniques and use them for their own profit. But Daoism is a whole, like Chinese medicine: you can't just take the foot or part of the body in isolation," said Master Hao. Explaining in more detail on another occasion, Wen stressed studying the lives of major figures in Daoist history, trying to understand the meaning of their actions, and taking inspiration from them; as well as reading and studying the major Daoist scriptures.

At the same time, the monks emphasized religious practices, extending beyond body and meditation techniques, to acts of worship as well. "Those who consider that rituals have no connection with cultivation are completely wrong", said Master Hu. Master Wen noted that Daoism had lost much of its spirit in recent centuries, paying too much attention to 
outer forms. At the same time, however, he stressed that the outer forms remain essential: "The problem of people trying to take some techniques and ignore the religion is common, also in China. They try to make a division between "Daoist philosophy" (daojia 道家) and “Daoist religion" (daojiao 道教). So people are surprised that I emphasize that outer forms are not important, but at the same time say that customs such as burning incense, and popular forms of worship, are essential. Even many Daoists say that such things are unimportant. But if that is so, why have they been transmitted down for so many centuries? There must be a deep significance to such acts".

Similarly, speaking of virtue, Wen elaborated and emphasized the importance of cultivating virtue $(d e)$ as a precondition of Daoist cultivation. From the questions asked by foreign Dream Trippers, and from our interviews with them, we know that virtue is not an explicit preoccupation for them: their chief interest is experiencing the $q i$ of the mountain, and secondly, to learn meditation techniques. In one anecdote related by Wen, he had been hired by a Russian Daoist tour group to take them to famous Daoist sites. "They were glad to learn techniques and mantras, but whenever I spoke about virtue and thought, they smirked and frowned. I told them how important it was, that without xinxing all the rest was useless, but they continued to frown. Later they came to me to expressly tell me to stop talking about morality! I felt sorry for them.”

$\mathrm{Hu}$ also stressed the relationship between a master and his disciples as a fundamental aspect of cultivation. One morning, the group had congregated in the shrine of the Great Lord of the Western Peak, mentioned above, to receive a teaching from him: a meditation technique, the Shining Heart (guangming xin 光明心). Several of the group participants entered into meditative posture during the explanation, and followed the instructions. During the question-and-answer session, a large, middle-aged, blonde American woman mentioned that she felt like crying, and had heart palpitations. "Very good, responded $\mathrm{Hu}$, the message is penetrating your heart".

For $\mathrm{Hu}$, these responses were not only due to the power of the place and of the meditation techniques, but to the emerging relationship of the group to him as a master. "It's not just a question of transmitting techniques: it is the power of the master that matters. Without the master's power, without a lineage, all of these techniques are of no use." For Hu, any trace of skepticism toward the master has the effect of interfering with the flow of power 
from the master to the students, thus damaging the “energy field” (qichang 氣場) created through the encounter. Hu's insistence on unquestioning belief aimed not to blindly impose some dogma, but to open the field for the mutual generation of a field of consciousness and perception, through an untrammeled communication of the imagination, of feelings, and even, through qi sensations, of somatic energies: a total fusion, orchestrated by the master, in which he and his disciples carry themselves away into the worlds of consciousness they have co-elaborated, realms in which the laws and limitations of ordinary life do not apply.

\section{Interpenetrations}

One evening, sitting in the darkness of the mountain dusk on the belvedere of the Eastern Court of Dao (Dongdaoyuan 東道院), a temple dedicated to the Mysterious Maiden of the Nine Heavens (jütian xuannü 九天玄女), Hu told the Dream Trippers stories of green-haired fairies who fluttered into the caverns and out into heaven. After hours of climbing and talking of caves, cultivation and the special powers of Huashan, the rumbling noises of civilization having been left in the dusty plains far below, while the spirits of all present were as carried upwards by the wispy breezes coiling around the pine trees and temple columns, gliding along the cliff walls, pouring into the grottoes and spreading into the nighttime void, all became as starry-eyed children listening to a bedtime story. The walls of self-defense and doubt had vanished, and the listeners ingested each of Hu's words like a magical elixir pill. Hu himself was carried into the imaginary world, describing the Immortal realms in vivid detail as if he were physically there. Indeed, several of those present, feeling flows of $q i$ in their groins and backbones as he spoke and chanted in his grave voice, were even as viscerally transported there. It was as if he had never known of any other world. At that moment, the spirits of Master Hu, the Dream Trippers and the Mysterious Maiden of the Nine Heavens conmingled in a single sacred place, moment and experience.

This vignette, and other encounters I have described elsewhere (see Palmer forthcoming) demonstrate how, in spite of the great distance which separates the "regions" of the Dream Trippers and the Quanzhen monks, the mutual experience of sacrality can generate significant points of contact between the two. On the one hand, while the 
Quanzhen monks experience and produce Huashan as part of a process of deep embedding in history, lineage, ritual and cosmology in the context of imperial and national state-building and cosmological projects, the Dream Trippers position Huashan in a process of disembedded energy collection by individuating subjects: the path along which they walk to Huashan is one that begins with Western struggles of self-affirmation, discovery of the body, technicization and detraditionalization (Siegler 2010, 2011). The Huashan they know, seek, and experience is one of virtually raw power. On the other hand, however, another scenario is beginning to unfold. For some Quanzhen monks, the national context of Daoism, with its scarred sacred places and politicized institutions (Goossaert \& Palmer 2011, Palmer 2009, Palmer forthcoming), is not a suitable environment for true Daoist cultivation; and they see a new space for reaching students and potential disciples among the global spiritual tourists. Master Hao is now building dormitories near his caves, in order to better accommodate larger groups of Western and Taiwanese practitioners. Master Wen, who was the vice abbott of Huashan when I began this project, has now left the Quanzhen monastic institution and gives teachings to visiting groups of Americans and Russians, and regularly goes to give instruction in Belgium on the invitation of a martial arts instructor who came to Huashan in the 2003 Dream Trip. At the same time, growing numbers of Western Daoist practitioners are unsatisfied with a primarily technical orientation to Daoist practice, and go to China seeking lineage and initiation into a more deeply embedded tradition. Some have formally taken Daoist monks as their master, and at least one other has even taken the step of becoming a Daoist nun herself, taking residence in a monastery. In this scenario, sacred sites such as Huashan are not merely locations colonized by supra-local processes of cosmological, political or economic hegemony, and are more than points in incommensurable "regions" overlapping and possibly confronting each other: their sacrality becomes a connecting node at which shared experiences and new relationships lead to them opening up to, mingling with, and interpenetrating each other.

\section{References}


Andersen, Poul. 1990. “A Visit to Huashan.” Cahiers d'Extrême-Asie 5: 349-354.

Appadurai, Arjun. 1996. Modernity at Large: Cultural Dimensions of Globalization. Minneapolis, MN: University of Minnesota Press.

Chen, Nancy. 2003. Breathing Spaces: Qigong, Psychiatry, and Healing in China. New York: Columbia University Press.

Chidester, David \& Edward T. Linenthal. 1995. Introduction. In American Sacred Space, edited by David Chidester and Edward T. Linenthal. Bloomington, IN: Indiana University Press, pp. 6-19.

Csordas, Thomas J. 2009. Introduction: Modalities of Transnational Transcendence. In Transnational Transcendence: Essays on Religion and Globalization, edited by Thomas J. Csordas. Berkeley: University of California Press, pp. 1-30.

Deleuze, Gilles and Félix Guattari. 1980. Mille plateaux. Capitalisme et schizophrénie 2. Paris: Editions de Minuit.

Digance, Justine. 2006. Religious and secular pilgrimage: Journeys redolent with meaning, in Tourism, Religion \& Spiritual Journeys, edited by Dallen J. Timothy and Daniel H. Olsen. Abingdon: Routledge, pp. 36-48.

Dott, Brian R. 2005. Identity Reflections: Pilgrimages to Mount Tai in Late Imperial China. Cambridge, MA: Harvard University Press.

Durkheim, Emile. 1994 [1913]. The Elementary Forms of the Religious Life: the Totemic System in Australia. In Durkheim on Religion, edited by W. S. F. Pickering, pp. 102-167. Atlanta, GA: Scholars Press.

Eliade, Mircea. 1958a. Patterns in Comparative Religion, trans. Rosamary Sheed, New York: Sheed \& Ward.

-- 1958b. The Sacred and the Profane: The Nature of Religion, trans. Willard W. Trask, New York: Harcourt, Brace and World.

Frøystad, Kathinka. 2009. The Return Path: Anthopology of a Western Yogi. In Transnational Transcendence: Essays on Religion and Globalization, edited by Thomas J. Csordas. Berkeley: University of California Press, pp. 279-304.

Goossaert, Vincent and David A. Palmer. 2011. The Religious Question in Modern China. Chicago: University of Chicago Press.

Herrou, Adeline. 2011. Networks and the "cloudlike wandering" of Daoist monks in China today, in Religion in Contemporary China: Revitalization and Innovation, edited by Adam Yuet Chau, pp. 108-132. London: Routledge. 
Hsu, Elizabeth. 1999. The Transmission of Chinese Medicine. Cambridge: Cambridge University Press.

Ingold, Tim. 2000. The Perception of the Environment: Essays on Livelihood, Dwelling and Skill. London and New York: Routledge.

Kohn, Livia. 2008. Chinese Healing Exercises. The Tradition of Daoyin. Honolulu: University of Hawaii Press.

Lagerwey, John. 2010. China: A Religious State. Hong Kong: University of Hong Kong Press.

Lane, Belden C. 2002. Landscapes of the Sacred: Geography and Narrative in American Spirituality. Baltimore: Johns Hopkins University Press.

Naquin, Susan \& Yü Chün-fang, eds. 1992. Pilgrims and Sacred Sites in China. Berkeley: University of California Press.

Oates, Tim and Donald Sutton, eds. 2010. Faiths on Display: Religion, Tourism, and the Chinese State. Lanham: Rowman and Littlefield.

Pahl, Jon. 2003. Shopping Malls and Other Sacred Spaces: Putting God in Place. Grand Rapids, MI: Brazos Press.

Palmer, David A. 2007. Qigong Fever: Body, Science and Utopia in China. New York: Columbia University Press.

-- 2008. Embodying Utopia: Charisma in the Post-Mao Qigong Craze. Nova Religio 12: 2, pp. 69-89.

-- 2009. China's Religious Danwei. Institutionalizing Religion in the Peoples' Republic. China Perspectives 4: 17-31.

-- forthcoming. Globalizing Daoism at Huashan: Quanzhen Monks, Danwei Politics and International Dream Trippers. In Quanzhen Daoism in Historical and Social Perspective, edited by Vincent Goossaert and Xun Liu. Berkeley: Institute of East Asian Studies.

Nederveen Pieterse, Jan. 2009. Globalization \& Culture: Global Mélange. Lanham: Rowman \& Littlefield.

Robertson, Roland. 1995. Glocalization: Time-Space and Homogeneity-Heterogeneity. In Global Modernities, edited by Mike Featherstone, Scott Lash and Roland Robertson. London: Sage, pp. 25-44.

Robson, James. 2009. Power of Place: The Religious Landscape of the Southern Sacred Peak (Nanyue) in Medieval China. Cambridge, MA: Harvard University Press.

Schipper, Kristofer. 2008. Comment on crée un lieu saint local. In La religion de la Chine: la tradition vivante by Kristofer Schipper, pp. 305-328. Paris: Fayard.

Siegler, Elijah. 2006. Chinese Traditions in Euro-American Society. In Chinese Religions in Contemorary Societies, edited by James Miller. Santa Barbara, CA.: ABC-CLIO, pp. 257-80. 
2010. 'Back to the Pristine': Identity Formation and Legitimation in Contemporary American Daoism. Nova Religio 14, no. 1 (2010), pp. 45-66.

2011. Daoism Beyond Modernity: The 'Healing Tao' as a Postmodern Movement. In Daoism in the 20 ${ }^{\text {th }}$ Century: Between Eternity and Modernity," edited by David A. Palmer and Liu Xun. Berkeley: University of California Press, pp. 274-292.

Siegler, Elijah and David A. Palmer. Forthcoming. Dream Trippers: Global Daoism and the Predicament of Modern Spirituality.

Tsing, Anna Lauwenhaupt. 2005. Friction: An Ethnography of Global Connection. Princeton: Princeton University Press.

Verellen, Franciscus, ed. 1998. Cultes des sites et culte des saints en Chine. Special issue, Cabiers d'Extrême-Asie 10.

von Glahn, Richard. 2004. The Sinister Way: The Divine and the Demonic in Chinese Religious Culture. Berkeley: University of California Press.

Winn, Michael. 5 Days in a Huashan cave. http://esoteric.2hav.net/printart.php?artid=216, accessed 4 Nov. 2010.

Yang, Mayfair. 2004. "Spacial Struggles: Postcolonial Complex, State Disenchantment, and Popular Reappropriation of Space in Rural Southeast China." Journal of Asian Studies 63:3, pp. 719-55. 